\author{
dr. sc. Damir Primorac \\ dr. sc. Maja Buhovac *" \\ Marko Pilić, mag. forens. "
}

\title{
TEORIJSKI I PRAKTIČNI ASPEKTI PRAVOSUDNE SURADNJE HRVATSKE I BOSNE I HERCECOVINE U POSTUPCIMA IZRUČEN]A VLASTITIH DRŽAVLJANA
}

Institut izručenja najstariji je oblik međunarodne pravne pomoći koji je među državama članicama Europske unije zamijenjen europskim uhidbenim nalogom. U odnosu na treće države kakva je Bosna i Hercegovina izručenje je jedini instrument kojim se omogućava transfer osoba koje se trebaju izručiti zbog vođenja kaznenog postupka, ili izvršenja kazne zatvora, ili zbog druge mjere koja podrazumijeva oduzimanje slobode u državi moliteljici. Radi stalna nastojanja da se osiguraju pravna sigurnost, načelo zakonitosti i vladavina prava, države kao subjekti međunarodnog prava svoje odnose na području ekstradicijskog prava sve više reguliraju potpisivanjem bilateralnih sporazuma kojima žele ostvariti taj cilj. U tom smjeru Hrvatska i Bosna i Hercegovina zaključile su 28. studenog 2012. Ugovor o izručenju koji se s tim datumom počeo privremeno primjenjivati, a stupio je na snagu 6. ožujka 2014. Ugovorom su, između ostalog, ekstenzivnije uređene odredbe o izručenju vlastitih državljana, čime se na određen način odstupilo od tradicionalnog načela neizručenja vlastitih državljana. Autori u radu analiziraju odredbe Ugovora o izručenju s posebnim osvrtom na odredbe o izručenju vlastitih državljana, osobito državljana koji imaju dvojno državljanstvo, što je nerijetko slučaj državljana Hrvatske i Bosne i Hercegovine. Mnoge države u Europi i svijetu tradicionalno se snažno protive izručenju vlastitih državljana. Načelo neizručenja vlastitih državljana pro-

Dr. sc. Damir Primorac, izvanredni profesor, Sveučilišni odjel za forenzične znanosti Sveučilišta u Splitu, Pravni fakultet Sveučilišta u Mostaru i odvjetnik (Associate Professor, University Department of Forensic Sciences, University of Split, Faculty of Law at University of Mostar and attorney-at-law):

damir.primorac@primorac-partners.com

ORCID ID: orcid.org/0000-0001-5036-4222

"Dr. sc. Maja Buhovac, docentica na Pravnom fakultetu Sveučilišta u Mostaru (Assistant Professor, Faculty of LawatUniversity of Mostar): maja.buhovac@pf.sum.ba

*** Marko Pilić, mag. forens., Sveučilišni odjel za forenzične znanosti Sveučilišta u Splitu, doktorand na Poslijediplomskome doktorskom studiju Međunarodni odnosi Sveučilišta u Zadru i Libertas međunarodnog sveučilišta u Zagrebu (University Department of Forensic Sciences University of Split, Ph.D. student at postgraduate studies of International relations at University of Zadar and Libertas International University Zagreb):mpilic@unist.hr

ORCID ID: orcid.org/0000-0002-4418-9306 
izlazi iz suverenosti država i njezinih državljana te obveza koje ih vežu, a osobito nepovjerenja u pravosudne sustave drugih država. Međutim, imajući u vidu da je temeljni cilj izručenja borba protiv nekažnjavanja osoba za koje se sumnja da su počinile kazneno djelo ili koje su osuđene za to, tada bi se nepovjerenje kao razlog neizručenja vlastitih državljana trebalo uzetis velikim oprezom. Da je načelo neizručenja vlastitih državljana u suvremenome kaznenom pravu zastarjelo, potvrđuje još i Konvencija o izručenju između država članica Europske unije navodeći da se izručenje ne smije odbiti s obrazloženjem da je osoba državljanin države moliteljice. Cilj je ovog rada analizom postojećega normativnog okvira i praktičnih primjera (ne) izručenja vlastitih državljana između Hrvatske i Bosne i Hercegovine upozoriti na probleme koji utječu na učinkovitu pravosudnu suradnju tih dviju država te ponuditi stajališta koja bi mogla pridonijeti razmatranju vrlo aktualnih pitanja.

Ključne riječi: pravosudna suradnja, ekstradicija, ugovor o izručenju, (ne)izručenje vlastitih državljana, sudska praksa.

\section{UVOD}

Pravosudna suradnja između država u suzbijanju kriminaliteta vrlo je dinamično područje u sveukupnim međunarodnim odnosima. Međunarodna kaznenopravna suradnja u užem je smislu ukupnost pravila kojima se uređuje djelatnost tijela kaznenog postupka u poduzimanju radnja na zahtjev tijela strane države.' Pravosudnom suradnjom države iskazuju svoju jasnu političku volju i spremnost za zajedničko i usklađeno suprotstavljanje različitim oblicima protupravnih ponašanja kojima se ugrožavaju vrijednosti o čijoj zaštiti postoji suglasnost na međunarodnoj razini. Među brojnim institutima pravosudne suradnje izručenje (ekstradicija) ${ }^{2}$ ima posebnu ulogu i značenje. U teoriji postoje različite definicije izručenja. Najčešće se pod tim pojmom podrazumijeva pravni posao među državama kojim se stranac ili osoba bez državljanstva na temelju pravnog postupka dovodi drugoj državi da bi joj se ondje sudilo za neko kazneno djelo ili da bi se nad njom provela kaznena sankcija. ${ }^{3}$ Temelj izručenja nalazi se u uzajamnoj koristi država da bude ostvareno njihovo pravo kažnjavanja primjenom vlastitih zakona prema svim osobama koje na njihovu teritoriju počine kazneno djelo. ${ }^{4}$

Osobito se za pravo izručenja vezuje pitanje (ne)izručenja vlastitih državljana koje je tradicionalno načelo prava izručenja. Njegovo podrijetlo nalazi se u suverenosti država i njihovih državljana, uzajamnim obvezama koje ih vežu te u nepovjerenju

\footnotetext{
Degan, Pavišić 2005, 281.

2 Izručenje (lat. extraditio) je predaja neke osobe iz vlasti jedne u vlast druge države radi provođenja kaznenog postupka ili izvršenja kazne. Horvatić 2002, 128.

3 Krapac 2006, 52.

4 Horović, Miljko 2014, 27.
} 
u pravosudne sustave drugih država. Stoga se među razlozima koji se ističu kao opravdanje tog načela osobito nalazi obveza države da zaštiti svoje državljane od primjene stranoga kaznenopravnog sustava čiji im postupci i jezik nisu poznati i u okviru kojeg se teško mogu braniti. ${ }^{5}$ Argumentu prema kojem se načelo neizručenja vlastitih državljana temelji na nepovjerenju država prema stranim pravosudnim sustavima prigovoreno je da je nepovjerenje vjerojatno jedan od temelja koji oblikuje način na koji se izručenje izvršava - i osobito odbija - do današnjih dana. Međutim, ako se nepovjerenjem može opravdati odluka države o neprihvaćanju zahtjeva za izručenje, teško da se njime može objasniti zašto se to odbijanje može odnositi samo na zahtjev za izručenje vlastitoga državljanina zbog njegova državljanstva. Takvo opravdanje vrijedilo bi za sve, a ne samo za vlastite državljane.

Nadalje, argumenti da osoba čije se izručenje traži ne poznaje jezik ili postupak druge države također nisu sasvim utemeljeni. Ne postoje nikakve zapreke da zamoljena država pomaže svom državljaninu u inozemstvu, posebice mehanizmom konzularne zaštite. Također se tvrdi da veza nacionalnosti obvezuje državu u odnosu na njezine državljane i zahtijeva od nje da osigura njihovu zaštitu. Dakako, država je dužna štititi svoje državljane, ali nije jasno zašto bi tu zaštitu trebala provoditi drukčije ovisno o tome nalazi li se njezin državljanin optužen za kazneno djelo počinjeno izvan svoje domovine $u$ inozemstvu ili na državnom teritoriju. Ako je u prvom slučaju prihvaćeno da će država ispunjavati svoju dužnost obavljanjem konzularne zaštite, zašto ne bi mogla učiniti istu stvar u slučaju vlastitoga državljanina čije je izručenje zatraženo? Te dvije situacije vidno se razlikuju samo činjenicom da kada je njezin državljanin na njezinu teritoriju, država može izvršavati svoju teritorijalnu suverenost i može ga odbiti izručiti, dok državne vlasti ne mogu učiniti ništa slično kada je njezin državljanin u inozemstvu. To pokazuje da odbijanje izručenja vlastitoga državljana više odgovara ostvarivanju suverene moći koja odgovara političkim razlozima nego ispunjavanju dužnosti zaštite.

Argument koji se također katkad iznosi u prilog neizručenja vlastitih državljana jest da se načelo neizručenja vlastitih državljana temelji na ideji da ako moraju odgovarati za svoje postupke na sudu, tim se osobama mora osigurati resocijalizacija koja bi bila učinkovitija u njihovoj domovini. No, ako se time može opravdati izvršenje kazne u zemlji državljanstva, to ne objašnjava zašto bi se odbilo izručenje vlastitoga državljana radi kaznenog progona u državi moliteljici. Neke države upravo idu u tom smjeru pa propisuju u svojim nacionalnim zakonima o izručenju da će odobriti izručenje vlastitoga državljana pod uvjetom njegova povratka u vlastitu zemlju radi odsluženja kazne. ${ }^{6}$

5 Deen-Racsmány, Blekxtoon 2005, 317.

6 Thouvenin 2012, 6. 
Suvremeno kazneno pravo nastoji stalnim dinamičnim izmjenama radi osiguranja vladavine prava osigurati učinkovite mehanizme kaznenopravne pomoći kojima je krajnji cilj borba i suzbijanje kriminaliteta. S obzirom na to da je izručenje postupak čiji je temeljni cilj borba protiv nekažnjavanja osobe koja se nalazi na nekome državnom području koje nije ono na kojemu je kazneno djelo počinjeno ${ }^{7}$, postavlja se pitanje je li došlo vrijeme da se načelo neizručenja vlastitih državljana na određen način ograniči kako bi se steklo povjerenje u pravosudne sustave drugih država i očuvalo načelo uzajamnog povjerenja. ${ }^{8}$ Stoga ovaj rad teži analizi temeljnih teorijskih $\mathrm{i}$ praktičnih aspekata u vezi s izručenjem vlastitih državljana između Hrvatske i Bosne i Hercegovine (dalje u tekstu: $\mathrm{BiH}$ ).

\section{POVIJESNO-PRAVNI PRIKAZ NEIZRUČENJA VLASTITIH DRŽAVLJANA}

Prvi slučaj odbijanja izručenja vlastitoga državljanina datira iz 1687. godine kada je engleski kralj James II. zahtijevao izručenje svoga državljanina Burneta kojeg su nizozemske vlasti odbile izručiti zato što je postao naturalizirani Nizozemac. ${ }^{9}$ Zabrana izručenja vlastitoga državljanina prvi se put na unutarnjem planu pojavila u belgijskom zakonu o izručenju 1833. godine, a na međunarodnom planu u belgijsko-francuskom ugovoru o izručenju 1834. godine.

Međutim, kod primjera Francuske uočavamo da načelo neizručenja vlastitih državljana nije uvijek imalo uporište u međunarodnim odnosima država. Tako je, primjerice, kao rezultat načela uzajamnosti nastao sporazum između Francuske i Nizozemske 1736. godine kojim su te dvije države dogovorile izručivati vlastite državljane. I drugi ugovori o izručenju, poput onog sa Švicarskom i Španjolskom, potvrđuju praksu izručenja vlastitih državljana. Prema nekim tvrdnjama Francuska je počela slijediti načelo neizručenja vlastitih državljana iz Povelje iz 1814. u kojem se navodi da "nitko ne smije biti ometen od svojih prirodnih sudaca“. Kasniji ugovori koje je Francuska potpisala potvrđuju načelo neizručenja vlastitih državljana, osim onog $\mathrm{s}$ Ujedinjenim Kraljevstvom iz $1843 .{ }^{10}$, iako praksa tih dviju država pokazuje da nisu izručivale vlastite državljane jedna drugoj."

\footnotetext{
7 Vidjeti presudu Europskog suda za ljudska prava, 4. rujna 2014., Trabelsi protiv Belgije, točka 117. u kojoj je Europski sud za ljudska prava naveo da „vodi računa o temeljnom razlogu za izručenje, a to je spriječiti da počinitelji kaznenih djela koji su u bijegu izbjegnu sudski postupak, kao i o cilju kojemu teži, koji je koristan za sve države u kontekstu eksternalizacije kriminaliteta“. Dostupno na https:// hudoc.echr.coe.int/eng\#\{\%22itemid\%22:[\%22001-146372\%22]\} (pristupljeno 1. 8. 2019.).

8 Načelo uzajamnog priznavanja temelji se na uzajamnom povjerenju u pravne sustave drugih država članica EU-a, a koje ne proizlazi iz same činjenice da je određena država članica EU-a, Hržina 2016, 12.

9 Thouvenin 2012, op. cit. (bilj. 3), str. 1.

10 Izmijenjen je Ugovorom o izručenju 14. kolovoza 1876. godine. Thouvenin 2012, op. cit., str. 7.

1 Posljednji tekst ugovora između Francuske i Ujedinjenog Kraljevstva isključuje izručenje vlastitih
} 
Načelo neizručenja vlastitih državljana danas ostaje čvrsto ukorijenjeno u domaćim zakonima i praksama država, i to ne samo u europskim državama kao što su Francuska, Belgija ili Njemačka. Ono se nalazi i u suvremenom zakonodavstvu Katara, Libanona, Čilea i mnogih drugih. To je i načelo ustavne vrijednosti, osobito u Njemačkoj, Estoniji, Grčkoj, Austriji, Poljskoj, Portugalu i Hrvatskoj.

S druge strane, zemlje common law pravne tradicije oduvijek imaju drukčiji pristup. Ujedinjeno Kraljevstvo ne nalazi bitan prigovor ideji o izručenju Britanaca. ${ }^{12}$ Štoviše, neizručenje bi značilo nekažnjivost za zločine počinjene u inozemstvu. Od 2003. godine određen broj njihovih državljana izručen je Sjedinjenim Američkim Državama (dalje u tekstu: SAD) kako bi im se sudilo za zločine počinjene u SAD-u. ${ }^{13}$ SAD poput Australije prihvaća istu doktrinu. Međutim, budući da je postupak izručenja u biti uređen primjenjivim ugovorima, $u$ tim će se zemljama i dalje primjenjivati načelo neizručenja vlastitih državljana ako ga ugovor u pravilu utvrđuje. SAD općenito to pokušava izbjeći, a nerijetko ishod pregovora u ugovorima o izručenju između SAD-a i zemlje koja obično odbija izručenje svojih državljana sadržava klauzulu koja se odnosi na to pitanje, gdje svaka strana postupa u skladu sa svojim domaćim zakonodavstvom. ${ }^{14}$ Štoviše, u SAD-u se vodila rasprava o tome je li oblik upućivanja na domaće pravo bio dovoljan za davanje ovlasti izvršnoj vlasti da izruči državljane SAD-a. Presudom iz 1936. Vrhovni sud negativno je ocijenio da odsutnost izričite odredbe u tom smislu zabranjuje izvršnoj vlasti izručenje vlastitih državljana, ali američki Kongres prihvatio je članak 3196. Zakona o izručenju iz 1990. godine koji daje državnom tajniku dostatne ovlasti za izručenje Amerikanaca iako sporazum to ne predviđa izričito. ${ }^{15}$ Također, Ugovor o izručenju između Kanade i Italije od 13. siječnja 2005. pred-

državljana, alije pri donošenju odluke o izručenju potrebno uzeti u obzir slučaj Burnet. To bi značilo da iznimka izručenja vlastitih državljana postoji, ali okolnost da je osoba stekla državljanstvo zamoljene države naturalizacijom neće spriječiti zamoljenu državu da izruči takva državljanina.

12 U svom izvješću o „Obvezi izručenja ili kaznenog progona“, A / CN.4 / 579 od 5. ožujka 2007. godine Komisija za međunarodno pravo izvješćuje o primjedbama i informacijama dobivenim od vlada: „Ujedinjeno Kraljevstvo izručuje pojedince (uključujući britanske državljane) koji su predmet zahtjeva za izručenje, pod uvjetom da izručenje nije zabranjeno po drugim osnovama (na primjer, humanitarni razlozi)“. Najnoviji slučajevi uključuju kaznena djela terorizma, 94, dostupno na http:// legal.un.org/docs/?path=../ilc/documentation/english/a_cn4_579.pdf\&lang=EFSX (pristupljeno 31. 7. 2019.).

13 Tako je, primjerice, Velika Britanija svoj prvi ugovor o izručenju sa SAD-om potpisala još 1794. godine u kojem se izručenje odnosilo na sve državljane, uključujući i vlastite. Shearer 1966, str. 276.

${ }_{14}$ Članak 3.1. Ugovora o izručenju između Francuske i Sjedinjenih Američkih Država od 23. travnja 1996., objavljen Uredbom br. 2002-117 od 29. siječnja 2002., propisuje da „zamoljena država neće biti obvezna odobriti izručenje jednog od svojih državljana, ali izvršna vlast SAD-a ima diskrecijsko pravo da to učini, prema vlastitom nahođenju, ako to smatra prikladnim“. Dostupno na https://www.legifrance.gouv.fr/affichTexte.do?cidTexte=JORFTEXTo00000218360\&categorieLien=id (pristupljeno 31. 7. 2019.).

${ }^{15}$ CherifBassiouni 2008, str. 326. 
viđa da „zamoljena država ne može odbiti izručenje osobe samo zbog toga što je državljanin zamoljene države."16

\section{PRAVNI IZVORI EKSTRADICIJSKOG PRAVA O (NE)IZRUČENJU VLASTITIH DRŽAVLJANA}

\subsection{Međunarodni izvori}

Premda je načelo neizručenja vlastitih državljana još neriješeno u međunarodnome običajnom pravu i njegova se praktična i moralna korist i dalje raspravlja, pravni izvori ekstradicijskog prava barem dopuštaju mogućnost državama strankama da odbiju izručenje vlastitih državljana. Tako Europska konvencija o izručenju od 13. prosinca 1957. godine (dalje u tekstu: Konvencija) ${ }^{17}$ propisuje pravo ugovornih stranaka da odbiju izručenje vlastitih državljana. ${ }^{18}$ Osim toga, države stranke Konvencije mogu priložiti izjavu kojom se definira značenje pojma "državljanin“ radi primjene Konvencije. Od 28 članica Europske unije (dalje u tekstu: EU) 19 država članica priložilo je izjave o neizručenju vlastitih državljana, što upućuje na široko oslanjanje na načelo neizručenja vlastitih državljana. Da bi se ograničila mogućnost neizručenja vlastitih državljana, u čl. 6., st. 2. Konvencije utvrđena je obveza države koja odbije izručenje vlastitoga državljanina da na zahtjev države moliteljice preda predmet svojim nadležnim tijelima koja, ako je to moguće, pokreću kazneni progon protiv predmetne osobe. Tako Konvencija obvezuje države na primjenu načela aut dedere aut iudicare.

Još je Hugo Grotius načelo aut dedere aut punire (ili izruči ili kazni) definirao na sljedeći način: „Kada je to od nje zatraženo, država mora kazniti krivca kad to zaslužuje ili ga predati u ruke države koja traži izručenje. ${ }^{19}$ Pojam „kazniti“ zamijenjen je pojmom „kazneno progoniti“ kao alternativa izručenju kako bi se poštovala presumpcija nevi-

${ }_{16}$ Članak V. Ugovora o izručenju između Kanade i Italije. Dostupno na https://www.treaty-accord. gc.ca/text-texte.aspx?id=105016 (pristupljeno 31. 7. 2019.).

17 Europska konvencija o izručenju u Hrvatskoj je stupila na snagu 25. travnja 1995. godine (Zakon o potvrđivanju Europske konvencije o izručenju od 13. prosinca 1957., Dopunskog protokola Europske konvencije o izručenju od 15. listopada 1975. i Drugoga dopunskog protokola Europske konvencije o izručenju od 17. ožujka 1978., NN-Međunarodni ugovori, br. 14/94). $\mathrm{U}$ odnosu na BiH stupila je na snagu 24. srpnja 2005. (Službeni glasnik BiH, Međunarodni ugovori, br. 04/05).

${ }_{18}$ Čl. 6. Konvencije. Izjave u vezi s neizručenjem vlastitih državljana dosad su podnijele Austrija, Bugarska, Hrvatska, Cipar, Estonija, Finska, Francuska, Njemačka, Crčka, Mađarska (s mogućnošću izručenja vlastitoga državljanina ako ima državljanstvo druge države i stalno prebivalište u njoj), Irska, Litva, Luksemburg, Nizozemska, Poljska, Portugal, Rumunjska (s mogućnošću izručenja ako ima državljanstvo i prebivalište druge države, ako će kaznu izvršavati u Rumunjskoj, ako je počinio djelo na teritoriju EU-a), Španjolska, Švedska.

19 Crotius 1724, 640. 
nosti na koju osobe za koje se sumnja da su počinile kazneno djelo imaju pravo. lako su Konvenciju ratificirale sve države članice Vijeća Europe i ona je pridonijela unifikaciji ekstradicijskog prava, ipak joj se pripisuju određeni nedostatci. Osim mogućnosti odbijanja izručenja vlastitih državljana, Konvencija propisuje mogućnost odbijanja izručenja počinitelja političkih kaznenih djela, prepušta uređenje postupka izručenja nacionalnim zakonodavstvima te predviđa mogućnost stavljanja rezervi na pojedine odredbe Konvencije, što je u praksi rezultiralo njezinom bilateralizacijom. ${ }^{20}$

Radi dopune Konvencije te drugih izvora ekstradicijskog prava u okviru EU-a donesena je Konvencija sastavljena na temelju članka K.3 Ugovora o EU-u o izručenju između država članica EU-a iz 1996. godine (Konvencija iz 1996.). ${ }^{21}$ Konvencija iz 1996. ambiciozan je pokušaj izuzimanja načela neizručenja vlastitih državljana jer predviđa u čl. 7. da se izručenje ne može odbiti jer je tražena osoba državljanin zamoljene države članice u smislu čl. 6. Konvencije. Pri obavljanju notifikacije svaka država članica može izjaviti da neće dopustiti izručenje svojih državljana ili će ga odobriti samo pod određenim posebnim uvjetima. U obrazloženju priloženom Vijeću navodi se da je st. 1. navedenog čl. 7. važan iskorak prema uklanjanju jedne od tradicionalnih zabrana izručenja između država članica. Razlozi za tu promjenu nalaze se u zajedničkim vrijednostima, zajedničkim pravnim tradicijama i uzajamnom povjerenju u ispravno funkcioniranje sustava kaznenog pravosuđa država članica EU-a. Stavak 2. predviđa mogućnost odstupanja od općeg načela utvrđenog u st. 1. Mogućnost rezerviranja u tom pogledu smatrala se prikladnom jer je zabrana izručenja vlastitih državljana utvrđena ustavima ili nacionalnim zakonima koji se temelje na dugogodišnjoj pravnoj tradiciji čija se promjena čini složenom. Međutim, st. 3. predviđa sustav koji će potaknuti reviziju izvršenih rezerva. Tako Konvencija iz 1996. predviđa da takve rezerve vrijede pet godina, ali se mogu obnoviti za uzastopna razdoblja od pet godina te propisuje da izostanak notifikacije u predviđenom roku prouzročuje istek rezerve.

Konvenciju iz 1996. ratificiralo je 15 od 28 država članica EU-a. Od toga je 13 priloženih izjava u skladu s čl. 7., st. 2. Konvencije iz 1996. Sljedećih šest država podnijelo je bezuvjetnu izjavu kategorički odbijajući izručenje svojih državljana: Austrija, Danska, Njemačka, Grčka, Latvija i Luksemburg. S druge strane, Belgija, Finska, Irska, Nizozemska, Portugal, Španjolska i Švedska izjavile su da će izručenje svojih državljana podvrgnuti određenim uvjetima (npr. jamstva na povratak za izdržavanje kazne, obostrana kažnjivost, uzajamnost, teroristička kaznena djela i organizirani kriminalitet, boravište u državi moliteljici itd). Ratifikacija Konvencije iz 1996. u većini sluča-

\footnotetext{
20 Hržina, Rošić, Stipišić 2012, 845.

${ }_{21}$ Konvencija sastavljena na temelju članka K.3 Ugovora o Europskoj uniji o izručenju između država članica Europske unije. Dostupna na https://eur-lex.europa.eu/legal-content/HR/TXT/?uri=CELEX\%3A41996A1023\%2802\%29 (pristupljeno 17. 7. 2019.)
} 
jeva trajala je najmanje četiri godine, pružajući dovoljno vremena čak i za ustavne promjene u većini zemalja. Međutim, takve izmjene i dopune nisu izvršene. Stoga, kako navode Deen-Racsmany i Blekxtoon, može se posumnjati da su dotične države uopće imale namjeru ratificirati Konvenciju iz 1996. kako bi promijenile svoje domaće zakonodavstvo u vezi s izručenjem vlastitih državljana u skladu s čl. 7. Ta činjenica uz velik broj izjava koje su na snazi osam godina nakon prihvaćanja Konvencije iz 1996. pokazuje njezin neuspjeh u tom pogledu. ${ }^{22}$

Najveći pomak u vezi s ograničenjem načela neizručenja vlastitih državljana učinjen je prihvaćanjem Okvirne odluke Vijeća od 13. lipnja 2002. o Europskom uhidbenom nalogu i postupcima predaje između država članica (dalje u tekstu: Okvirna odluka o EUN-u. ${ }^{23}$ Članci 3. i 4. Okvirne odluke o EUN-u propisuju razloge za obvezno neizvršenje EUN-a i razloge za moguće neizvršenje EUN-a. Međutim, EUN još propisuje državljanstvo kao izborni razlog odbijanja izvršenja EUN-a, ali se na njega može pozivati samo pod određenim uvjetima. Tako čl. 4., st. 6. Okvirne odluke o EUN-u propisuje da se izvršenje EUN-a može odbiti ako je državljanin ili stanovnik države izvršiteljice tražen zbog izvršenja kazne zatvora ili oduzimanja slobode, pod uvjetom da se ta država članica obvezuje izvršiti tu kaznu ili mjeru oduzimanja slobode u skladu s odredbama svojega domaćeg prava. Poseban odnos države prema vlastitim državljanima reguliran je u čl. 5. Okvirne odluke o EUN-u koji propisuje jamstva koja mora u nekim slučajevima pružiti država izdavateljica EUN-a. Tako je u st. 3 propisano da ako je tražena osoba državljanin države izvršiteljice, predaja te osobe može biti podložna uvjetu da ta osoba nakon saslušanja bude vraćena u državu izvršiteljicu kako bi u njoj izdržala kaznu zatvora ili mjeru oduzimanja slobode koja joj je izrečena u državi izdavateljici.

\subsection{Unutarnji propisi prava izručenja vlastitih državljana}

Većina europskih ustava uređuje pitanje državljanstva naglašavajući pravnu vezu između države i njezina državljanina pravima i obvezama koja mu po tome pripadaju. Sve donedavno stavljao se naglasak na to kako se državljaninu ne može oduzeti državljanstvo, prognati ga se iz države ni izručiti drugoj državi. Međutim, državljanstvo kao pojam internog prava nije moglo izbjeći međunarodnopravne implikacije gdje se o posebnim pravnim učincima državljanstva raspravlja na međunarodnoj razini. ${ }^{24}$ Pitanje izručenja između država počelo se rješavati polovicom prošlog stoljeća multilateralnim sporazumima ili bilateralnim ugovorima. No, ustavi su sve donedavno ustrajavali na ideji o neizručenju, odnosno zabrani izručenja vlastitih državljana.

22 Deen-Racsmány, Blekxtoon 2005, op. cit., 325-327.

${ }^{23}$ O tome vidjeti kod: Primorac, 2018, 21.

${ }^{24}$ Horović, Miljko 2014, op. cit., 30. 
Tako je, primjerice, Temeljnim zakonom Savezne Republike Njemačke (Crundgesetz für die Bundesrepublik Deutschland) od 23. svibnja 1949. godine bilo propisano da nijedan Nijemac ne smije biti izručen u inozemstvo. Člankom 16., st. 2. Temeljnog zakona koji je posljednji put izmijenjen 23. prosinca 2014. godine određuje se: „Nijedan Nijemac ne smije se izručiti u inozemstvo. Zakonom se može donijeti odstupajući propis za izručenje državi članici EU-a ili međunarodnom sudu pod uvjetom da su zajamčena načela vladavine prava. ${ }^{{ }_{25} 5} \mathrm{Na}$ sličan je način definirano čl. 9., st. 3. finskog Ustava ${ }^{26}$ da nijedan finski državljanin ne smije protiv svoje volje biti izručen ili predan drugoj državi. Zakonom se, međutim, može predvidjeti mogućnost izručenja, odnosno transfera finskoga državljanina zbog kaznenoga djela ili radi vođenja postupka državi u kojoj su zajamčena njegova temeljna prava i sudska zaštita. Ustav Švicarske Konfederacije u čl. 25. propisuje da švicarski državljani ne mogu biti prognani iz zemlje. Mogu biti izručeni stranoj vlasti samo ako na to pristanu. ${ }^{27} \mathrm{U}$ latvijskom Ustavu u čl. 98., st. 3. predviđeno je: „Latvijski državljanin ne može biti izručen drugoj državi, osim u slučajevima predviđenima u međunarodnim ugovorima koje je ratificirao parlament (Saeima), pod uvjetom da se izručenjem ne krše temeljna prava zajamčena Ustavom. ${ }^{{ }^{2} 8}$

Kad je riječ o Hrvatskoj i BiH, kao države nastale raspadom Jugoslavije nastavile su tradiciju neizručenja vlastitih državljana. ${ }^{29}$ Tako hrvatski Ustav u čl. 9. propisuje da hrvatski državljanin ne može biti izručen drugoj državi, osim kad se mora izvršiti odluka o izručenju ili predaji donesena u skladu s međunarodnim ugovorom ili pravnom stečevinom EU-a. Ta ustavna promjena iz 2010. godine pokazatelj je napuštanja tradicionalnog načela neizručenja vlastitih državljana poput navedenih europskih ustava. Tako sam Ustav poziva na poštivanje bilateralnih ugovora te ostavlja mogućnost državama da pitanje izuzeća državljanstva drukčije urede.

S druge strane, imajući u vidu specifičnost ustavnog uređenja u BiH, uočavamo kako se Ustav BiH kao aneks međunarodnoga mirovnog sporazuma uopće ne bavi tim

${ }_{25}$ Izmjene i dopune Temeljnog zakona (Crundgesetzänderung, Cesetz zur Änderung des Crundgesetzes (Artikel 16), BCBI. I 2000), dostupno na https://dejure.org/BCBI/2000/BCBI._I_S._1633b (pristupljeno 27. 8. 2019.).

${ }^{26}$ Finski ustav (Suomen perustuslaki 11.6.1999/731), dostupno na https://www.finlex.fi/fi/laki/ajantasa/1999/19990731 (pristupljeno 27. 8. 2019.).

${ }_{27}$ Ustav Švicarske Konfederacije (Constitution fédérale de la Confédération suisse du 18 avril 1999 (Etat le 23 septembre 2018), dostupno na https://www.admin.ch/opc/fr/classified-compilation/19995395/index. html (pristupljeno 28. 8. 2019.).

${ }^{28}$ Ustav Republike Latvije (Latvijas Republikas Satverse 15.2.1922.), dostupno na https://likumi.Iv/doc. php?id=57980 (pristupljeno 28. 8. 2019.).

29 Zakon o krivičnom postupku SFR], Službeni list SFR], br. 4/77, 36/77, 60/77, 14/85, 26/86, 74/87, 57/89, 3/90 i Službeni list SRJ, br. 27/92, 24/94, 13/01 propisuje glavi XXXI. pod naslovom „Postupak za izdavanje i okrivljenih i osuđenih lica“ u čl. 525. da je pretpostavka za izdavanje da „lice čije se izdavanje traži nije državljanin SFR]“. 
pitanjima. Ustav BiH sadržava odredbe o državljanstvu ${ }^{30}$, ali ne sadržava ustavnu odredbu o zabrani izručenja vlastitih državljana. Pitanje izručenja prepušteno je nižim pravnim aktima, odnosno zakonima. Glavni je izvor domaćega ekstradicijskog prava u Hrvatskoj Zakon o međunarodnoj pravnoj pomoći u kaznenim stvarima (dalje u tekstu: ZMPPKS RH) ${ }^{31}$, a u BiH istoimeni zakon (dalje u tekstu: ZMPPKS BiH). ${ }^{32}$ Oba zakona potvrđuju tradicionalno načelo neizručenja vlastitih državljana. ZMPPKS RH propisuje da hrvatski državljanin ne može biti izručen radi kaznenog progona ili izvršenja kazne zatvora stranoj državi, dok ZMPPKS BiH navodi pretpostavke za izručenje, a prva je od njih da osoba čije se izručenje traži nije državljanin $\mathrm{BiH} \cdot{ }^{33}$

\subsection{Ugovor o izručenju između Hrvatske i BiH}

Prije potpisivanja ugovora o izručenju koji se smatra glavnim pravnim izvorom pravosudne suradnje tih dviju država na području prava izručenja, Hrvatska i BiH potpisale su nekoliko bilateralnih sporazuma ${ }^{34}$ koji ne uređuju materiju izručenja vlastitih državljana. Temeljni je pravni izvor u ostvarenju učinkovite pravosudne suradnje na području ekstradicije između Hrvatske i BiH Ugovor o izručenju (dalje u tekstu: Ugovor). ${ }^{35}$ Ugovor je potpisan 28. studenog 2012. godine kada se počeo privremeno primjenjivati, a na snagu je stupio 6. ožujka 2014. godine. ${ }^{36}$ Ugovor je zaključen radi nastavka pravosudne suradnje i stalne borbe protiv svih oblika kriminaliteta, osobito onih teških. Taj je čin određen pomak u ostvarenju učinkovite pravosudne suradnje između Hrvatske i BiH jer su njime određena sporna pitanja iz Konvencije ograničena ili ukinuta. Tako Ugovorom nisu uređena pitanja odbijanja izručenja u slučaju počinjenja vojnih i političkih kaznenih djela kako je regulirano Konvencijom. Međutim, izručenje u tom slučaju bilo bi suprotno obvezama zamoljene države koje proizlaze iz Konvencije, što je obvezni razlog za odbijanje izručenja.

30 Čl. I. 7. Ustava BiH.

${ }_{31}$ Zakon o međunarodnoj pravnoj pomoći u kaznenim stvarima, NN, br. 178/04.

32 Zakon o međunarodnoj pravnoj pomoći u kaznenim stvarima, Službeni glasnik BiH, br. 53/09, $58 / 13$.

33 Čl. 32. ZMPPKS-a RH i čl. 34. ZMPPKS-a BiH.

${ }^{34}$ Sporazum između Vlade BiH, Vlade FBiH i Vlade Hrvatske o pravnoj pomoći u građanskim i kaznenim stvarima s posebnim dodatkom, NN-Međunarodni ugovori, br. 12/96 i Sporazum između Vlade $\mathrm{BiH}$, Vlade FBiH i Vlade RH o međusobnom izvršavanju sudskih odluka u kaznenim stvarima, Službeni list RBiH-Međunarodni ugovori, br. 1/96. Vidjeti u: Sladoje, Bučar, Pilav, Šarac 2006, 299-321.

35 Ugovor između Republike Hrvatske i Bosne i Hercegovine o izručenju, NN-Međunarodni ugovori, br. 1/14, Službeni glasnik BiH, Međunarodni ugovori, br. 22/12.

${ }_{36}$ Ugovore o izručenju Hrvatska je potpisala i sa zemljama iz regije, i to sa Srbijom 29. lipnja 2010. godine, s Crnom Corom 1. listopada 2010. godine, s Makedonijom 31. listopada 2011. godine, a BiH sa Srbijom 5. rujna 2013. godine, s Crnom Corom 15. studenog 2012. godine, s Makedonijom 27. siječnja 2006. godine s izmjenama i dopunama o izručenju vlastitih državljana od 12. ožujka 2013. godine. 
Najveći iskorak u vezi s tim pravnim izvorom dogodio se reguliranjem pitanja izručenja vlastitih državljana. Ugovor je odstupio od tradicionalnog načela neizručenja vlastitih državljana iako predviđa određena ograničenja. Tako je čl. 7. Ugovora predviđeno izručenje vlastitih državljana radi kaznenog progona za kaznena djela organiziranoga kriminaliteta, korupcije i pranja novca za koja je prema pravu obiju država propisana kazna zatvora ili mjera oduzimanja slobode od četiri godine ili teža kazna, a radi izvršenja kaznene sankcije ako trajanje zatvora ili oduzimanja slobode odnosno njihov ostatak koji se treba izvršiti iznosi najmanje dvije godine. Ugovor nadalje propisuje koja su kaznena djela organiziranoga kriminaliteta, a koja koruptivna kaznena djela. Tako u kaznena djela organiziranoga kriminaliteta ulaze kaznena djela za koja je propisana kazna zatvora od četiri godine ili teža kazna, a koja je počinila organizirana zločinačka skupina, u skladu s domaćim pravom te organiziranje i pripadanje organiziranoj zločinačkoj skupini.

U koruptivna kaznena djela prema čl. 7., st. 4. Ugovora ulaze zlouporaba položaja službene ili odgovorne osobe, aktivno i pasivno protuzakonito posredovanje korištenjem utjecaja, aktivno i pasivno podmićivanje službene osobe, aktivno i pasivno podmićivanje u privatnom sektoru te pronevjera. Da bi se ograničilo neizručenje vlastitih državljana, Ugovorom je propisano da će se izručenje vlastitih državljana radi kaznenog progona dopustiti i za ona teška kaznena djela za koja se može izreći kazna zatvora od deset godina ili teža kazna, a radi izvršenja kaznene sankcije ako trajanje kazne zatvora, odnosno njezin ostatak iznosi najmanje pet godina. Još jedna novina koja je uređena Ugovorom mogućnost je preuzimanja izvršenja strane sudske odluke kojom su osuđeni vlastiti državljani. O toj mogućnosti zamoljena će država obavijestiti osobu čije se izručenje traži te ako ona pristane na to, zamoljena država obavijestit će državu moliteljicu da u roku ne duljem od 10 dana može podnijeti zamolbu za preuzimanje izvršenja kaznene sankcije. Ako država moliteljica ne podnese zamolbu u navedenom roku, provodi se postupak izručenja. U slučaju da država moliteljica podnese zamolbu za preuzimanje izvršenja, zamolba za izručenje smatrat će se zamolbom za privremeno pritvaranje osobe radi osiguranja njezine prisutnosti do pravomoćnog okončanja postupka preuzimanja izvršenja sudske odluke. ${ }^{37}$

U praksi se nakon prihvaćanja Ugovora postavilo pitanje njegove primjene u odnosu na kaznena djela za koja će se dopustiti izručenje vlastitih državljana. Vrijedi li izručenje vlastitih državljana za kaznena djela počinjena nakon potpisivanja Ugovora ili njegovim stupanjem na snagu, jasno je razgraničeno odredbom čl. 34. Ugovora. Ona navodi da se odredbe koje se odnose na izručenje vlastitih državljana primjenjuju samo za kaznena djela počinjena nakon datuma potpisivanja Ugovora, dakle od 28.

37 Čl. 9. Ugovora. 
studenog 2012. godine. Analizirajući čl. 18., st. 2. Ugovora uočavamo da te odredbe ublažavaju zabranu izručenja vlastitoga državljanina jer je njime propisana situacija kada bi zbog odgode izručenja u državi moliteljici mogla nastupiti zastara kaznenog progona ili se u prisutnosti osobe čije se izručenje traži trebaju provesti dokazne radnje za koje postoji opasnost od odgode. U tim slučajevima može se dopustiti privremeno izručenje te osobe. Kako ni Konvencija ni Ugovor ne navode izričito za koje se državljane može tražiti privremeno izručenje, pretpostavljamo da se to odnosi i na vlastite državljane. Kad je riječ o privremenom pritvoru u postupku izručenja, jedina je novina u odnosu na Konvenciju što je Ugovorom propisano da se međunarodna tjeralica smatra zamolbom za privremeno pritvaranje.

Uspoređujući odredbe Ugovora što se tiču izručenja vlastitih državljana s ugovorima o izručenju između drugih država, možemo reći da je taj Ugovor hrabar iskorak ograničenju načela neizručenja vlastitih državljana. Primjerice, u Ugovoru o izručenju od 3. veljače 1993. godine između Republike Latvije i Ruske Federacije u čl. 62. propisano je da se izručenje neće dopustiti ako je osoba čije se izručenje traži državljanin ugovorne strane ili ako ta osoba u toj državi ima status izbjeglice. Takvu odredbu sadržava i Ugovor o izručenju između Francuske i Maroka. Nešto blažu odredbu sadržava Ugovor o izručenju između Savezne Republike Njemačke i SAD-a ${ }^{38}$ koji navodi u čl. 7., st. 1.: „Ugovorne stranke nisu obvezne izručivati vlastite državljane...."

\section{TEORIJSKA PROBLEMATIKA PRAVA IZRUČENJA VLASTITIH DRŽAVLJANA}

Na međunarodnoj razini trenutačno se raspravlja o nekoliko pitanja u vezi s izručenjem vlastitih državljana, a koja su problematična i u vezi s Hrvatskom i BiH. Da bi se moglo opravdati načelo neizručenja vlastitih državljana, prvo se postavlja pitanje pravne osnove za utvrđivanje državljanstva osobe čije se izručenje traži kao i pitanje od kojeg trenutka osoba mora imati državljanstvo određene države da bi se moglo odbiti njezino izručenje. Osim toga, osobito je sporno pitanje dvostrukoga državljanstva koje dodatno otežava izručenje, zatim načelo obostrane kažnjivosti te pitanje izručenja u skladu s načelom nediskriminacije na temelju državljanstva.

\footnotetext{
${ }^{38}$ Ugovor o izručenju između Savezne Republike Njemačke i Sjedinjenih Američkih Država od 20. lipnja 1978. U skladu s čl. 17., st. 2. Ugovora o izručenju između EU-a i SAD-a navodi se: „Ako ustavna načela države kojoj je podnesen zahtjev mogu predstavljati prepreku ispunjenju njezinih obveza izručenja, a rješenje tog pitanja nije predviđeno u Ugovoru o izručenju između EU-a i SAD-a ili mjerodavnom bilateralnom ugovoru, održavaju se savjetovanja između države kojoj je podnesen zahtjev i države koja podnosi zahtjev." Dakle, u načelu, tim čl. 17. omogućava se državi članici da na temelju odredaba bilateralnog sporazuma, odnosno svojih ustavnopravnih pravila zadrži posebno postupanje prema svojim domaćim državljanima zabranom njihova izručenja.
} 


\section{a) Državljanstvo i status državljanina u postupku izručenja}

Državljanstvo je poseban pravni odnos koji postoji između države i pojedinca i iz kojeg proizlazi niz prava i obveza s obiju strana. U vezi s državljanstvom postavlja se pitanje pravne osnove za utvrđivanje državljanstva u slučaju izručenja vlastitih državljana. Zamoljena država može se protiviti izručenju vlastitih državljana na temelju svoga domaćeg prava kada se konvencija o izručenju odnosi na potonje u pogledu moguće primjene tog pravila ${ }^{39}$, ili u primjeni međunarodnog prava kada konvencija izričito navodi da države mogu ili moraju odbiti izručiti svoje državljane.

Jasno je da su unutarnji propisi relevantni za utvrđivanje državljanstva jer ono i proizlazi iz suverenosti države. U Hrvatskoj je to Zakon o hrvatskom državljanstvu ${ }^{40}$, a u BiH Zakon o državljanstvu Bosne i Hercegovine. ${ }^{41}$ Međutim, imajući u vidu da je izručenje mješovit pravni institut na koji se primjenjuju odredbe i nacionalnog, ali i supranacionalnog prava, osobito što se tiče obveza koje proizlaze za države iz multilateralnih i bilateralnih ugovora, postavlja se pitanje hoće li država svoje pravo ili obvezu da se suprotstavi izručenju vlastitoga državljana prepustiti Konvenciji ili nacionalnom propisu pri utvrđivanju statusa državljanina.

No, analizirajući odredbe Konvencije, uočavamo da ona implicitno upućuje na unutarnje zakonodavstvo svake države pri procjeni pojma državljanin. Analiza odredaba o pojmu "državljanin“ iz pojedinih nacionalnih zakonodavstava pokazuje kako je taj pojam različito determiniran. ${ }^{42}$ Posebno je pitanje u vezi s pojmom "državljanin“ u kojem trenutku osoba mora imati državljanstvo države koja odlučuje o ekstradiciji. Tako se primjerice $u$ francuskom, andorskom i hrvatskom zakonodavstvu status državljanina određuje prema trenutku počinjenja kaznenoga djela, dok se u nekim drugim pravnim sustavima, poput austrijskog, švicarskog i njemačkog, status državljanina određuje prema trenutku postupka izručenja. Postoje i pravni sustavi koji status državljanina određuju prema trenutku prijama zahtjeva za izručenje, poput bugarskog zakonodavstva, ili oni koji državljanstvo određuju u trenutku donošenja odluke o izručenju poput Ukrajine i Armenije.

S druge strane, države poput BiH koje nisu pri ratifikaciji Konvencije priložile izjavu o pojmu „državljanin“, jasno su dale prednost Konvenciji u vremenskom određivanju tog pojma, a to je u skladu s čl. 6., t. c) Konvencije prema trenutku donošenja odluke o izručenju. Iz toga proizlazi da se neće izručiti ni osoba koja je državljanstvo BiH

\footnotetext{
39 Primjerice, čl. 2., st. 3. Međuameričke konvencije o izručenju: „Zamoljena država može uskratiti izručenje kada je prema vlastitom zakonodavstvu nadležna za kazneni progon osobe čije se izručenje traži za djelo na kojem se zahtjev temelji. Ako iz tog razloga odbije izručenje, zamoljena država podnosi slučaj svojim nadležnim tijelima i obavještava državu moliteljicu o rezultatu."

40 Zakon o hrvatskom državljanstvu, NN, br. 53/91, 28/92, 113/93, 4/94, 130/11, 110/15.

${ }^{41}$ Zakon o državljanstvu Bosne i Hercegovine, Službeni glasnik BiH, br. 4/97, 13/97, 41/02, 6/03, 14/03.

${ }^{42}$ Vidjeti različite definicije pojma „državljanin“ u : Thouvenin 2012, op. cit. (bilj. 34), str. 8.
} 
stekla nakon počinjenja kaznenoga djela. Dakle, u vezi s tim pitanjem ne postoji univerzalni pristup država u određivanju trenutka od kojeg osoba čije se izručenje traži mora imati državljanstvo određene države da bi se ono moglo odbiti. Osim toga, sudska praksa u Hrvatskoj pokazuje da se kao činjenice relevantne kao smetnje za izručenje ne mogu uzeti brak s hrvatskim državljaninom, podrijetlo od hrvatskih roditelja, ili vlasništvo nad nekretninama u Hrvatskoj, ili npr. samo postavljeni zahtjev okrivljenika za (ponovni) primitak u hrvatsko državljanstvo koji u vrijeme donošenja odluke o izručenju nije dovršen; no jedanput stečeno hrvatsko državljanstvo smetnja je za izručenje sve dok pravomoćnom odlukom u ponovljenom postupku zbog predočavanja lažnih isprava ono ne bude oduzeto zato što je nadležno tijelo takvim ispravama bilo dovedeno u zabludu pri upisu u knjigu državljana. Ako tražena osoba stekne državljanstvo zamoljene države između donesene odluke o izručenju i predviđenog trenutka izvršenja odluke o izručenju, zamoljena država može naknadno odbiti izručenje. ${ }^{43}$

\section{b) Dvojno državljanstvo}

Činjenica da je osoba čije se izručenje traži državljanin i države moliteljice i zamoljene države ne utječe na primjenu načela neizručenja vlastitih državljana na što upozorava praksa pojedinih država. Najveći problemi dvojnoga državljanstva u vezi s primjenom načela neizručenja vlastitih državljana nastaju uglavnom u slučajevima kada je državljanstvo zamoljene države dobiveno nakon počinjenja kaznenih djela koja su predmet optužnice ili presude na temelju kojih se traži izručenje predmetne osobe. Države od kojih se traži izručenje ne uzimaju u obzir drugo državljanstvo svoga državljanina. Kao povijesni primjer neizručenja poznat je slučaj iz 1941. godine kada je Meksiko odbilo izručiti Alejandra Ramireza Hinojosa u SAD, koji je bio Amerikanac po rođenju, a Meksikanac po krvi. ${ }^{44}$ Kad je riječ o Hrvatskoj i $\mathrm{BiH}$, one su potpisale Ugovor o dvojnom državljanstvu ${ }^{45}$ prema kojem je propisano da se dvojni državljanin kada se nalazi na državnom području $\mathrm{BiH}$, odnosno Hrvatske, smatra isključivo državljaninom one ugovorne stranke na čijem se državnom području nalazi te da uživa sva prava koja ima i uživa državljanin ugovorne stranke na čijem se državnom području nalazi i dužan je ispunjavati sve obveze državljanina te ugovorne stranke. U kontekstu izručenja dvojno državljanstvo dodatno potvrđuje načelo neizručenja vlastitih državljana jer omogućuje izbjegavanje procesuiranja osoba koje imaju državljanstvo i države moliteljice i zamoljene države.

\footnotetext{
43 Krapac 2005, 652-653.

44 Thouvenin 2012, op. cit. (bilj. 44), str. 10.

45 Ugovor između Republike Hrvatske i Bosne i Hercegovine o dvojnom državljanstvu, NN, br. 9/07, Službeni glasnik BiH-Međunarodni ugovori, br. 10/11.
} 
S druge strane, postoje i pravni sustavi koji predviđaju izručenje vlastitih državljana koji imaju dvojno državljanstvo, odnosno državljanstvo i neke druge države. Tako Mađarska predviđa izručenje vlastitoga državljanina ako ima državljanstvo druge države i stalno prebivalište u njoj, dok Rumunjska propisuje mogućnost izručenja vlastitoga državljanina ako ima državljanstvo i prebivalište druge države, ako će kaznu izvršavati u Rumunjskoj te ako je počinio kazneno djelo na teritoriju EU-a.

Cledajući s kaznenopravnog aspekta, dvojno državljanstvo na području prava izručenja nije ništa drugo nego povlastica na temelju koje dvojni državljanin izbjegava kazneni progon ili izvršenje kaznene sankcije. Međutim, i u tom slučaju postoje mehanizmi kaznenopravne pomoći koji omogućuju da osobe s dvostrukim državljanstvom ne ostanu neprocesuirane. Tako je čl. 17. Ugovora predviđeno da kada država moliteljica traži izručenje osobe radi izvršenja kazne zatvora ili druge mjere koja uključuje oduzimanje slobode izrečene protiv te osobe u njezinoj odsutnosti, zamoljena država dopustit će izručenje ako država moliteljica u skladu sa svojim zakonodavstvom pruži jamstvo da će izručena osoba imati pravo na ponavljanje postupka koji će se provesti u njezinoj prisutnosti. No, ta mogućnost bit će ograničena za BiH jer se prema Zakonu o kaznenom postupku BiH (dalje u tekstu: ZKP BiH) ne može voditi postupak u odsutnosti. ${ }^{46} \mathrm{U}$ odnosu na pravosudnu suradnju Hrvatske i BiH dvojno državljanstvo više ne može biti zapreka za neizručenje vlastitih državljana na što upućuje i novija sudska praksa. ${ }^{47}$ Takva je praksa rezultat primjene odredaba Ugovora kojima je ograničeno načelo neizručenja vlastitih državljana.

\section{c) Načelo obostrane kažnjivosti}

Načelo obostrane kažnjivosti ${ }^{48}$, poznato kao načelo identiteta norme (istovjetnosti norme), znači da će se izručenje dopustiti samo ako je kazneno djelo zbog kojeg se izručenje traži kažnjivo po zakonima i države moliteljice i zamoljene države. Prema odredbama Ugovora, da bi se dopustilo izručenje vlastitih državljana, potrebno je utvrditi da su djela s popisa propisana kao kaznena djela u obama zakonodavstvima. ${ }^{49}$ Tako je, primjerice, u jednome ekstradicijskom predmetu utvrđeno da se kazneno djelo organizirani kriminalitet iz čl. 342. Kaznenog zakona FBiH (dalje u tekstu: $\mathrm{KZ} \mathrm{FBiH})^{50}$ može po bitnim obilježjima podvesti pod kazneno djelo počinjenje kaznenoga djela u sastavu zločinačkog udruženja iz čl. 329. hrvatskoga Kaznenog za-

\footnotetext{
${ }_{46}$ Čl. 247. Zakona o kaznenom postupku BiH, Službeni glasnik Bosne i Hercegovine, br. 3/03, 32/03, 36/03, 26/04, 63/04, 13/05, 48/05, 46/06, 29/07, 53/07, 58/08, 12/09, 16/09, 53/09, 93/09, 72/13 i 65/18.

47 Vidjeti infra, 18 i dalje.

${ }^{48}$ Derenčinović, 2014, 2-3.

49 Vidjeti o dvostrukoj kažnjivosti kod: Primorac, Krmek, Pilić 2015, 109.

50 Kazneni zakon FBiH, Službene novine Federacije BiH, br. 36/03, 21/04 - ispr., 69/04, 18/05, 42/10, 42/11, 59/14, 76/14, 46/16, 75/17.
} 
kona (dalje u tekstu: KZ RH) ${ }^{51}$ koji propisuje da „tko znajući za cilj zločinačkog udruženja ili njegove kriminalne aktivnosti počini kazneno djelo u sastavu takva udruženja ili potakne drugoga na počinjenje kaznenog djela u sastavu takva udruženja, kaznit će se za kazneno djelo za koje je propisana gornja granica kazne...". Također je utvrđeno da se kazneno djelo zlouporabe položaja ili ovlaštenja iz čl. 383. KZ-a FBiH može po bitnim obilježjima podvesti pod kazneno djelo zlouporaba položaja i ovlasti iz čl. 291. KZ-a RH koji propisuje da "službena ili odgovorna osoba koja iskoristi svoj položaj i ovlast, prekorači granice svoje ovlasti ili ne obavi dužnost pa time sebi ili drugoj osobi pribavi znatnu imovinsku korist ili prouzroči znatnu štetu, kaznit će se kaznom zatvora.....52

\section{d) Načelo nediskriminacije na temelju državljanstva u postupcima izručenja}

Sud EU-a u novijoj judikaturi našao se pred izazovom različitih tumačenja Ugovora o funkcioniranju EU-a (dalje u tekstu: UFEU), osobito čl. 18. i čl. 21., a koja pokazuju široko oslanjanje na načelo neizručenja vlastitih državljana. Sudu EU-a postavilo se pitanje treba li zaštitu protiv izručenja na koju imaju pravo državljani države članice na temelju svoga nacionalnog prava ili bilateralnog ugovora s trećom državom, u skladu s odredbama UFEU-a koje se odnose na građanstvo EU-a, proširiti i na državljane drugih država članica kada zahtjev za izručenje dolazi od treće države. Sud EU-a u tom je predmetu odlučio da čl. 18. i 21. UFEU-a treba tumačiti tako da, kada je državi članici u kojoj se nalazi građanin EU-a - državljanin druge države članice - upućen zahtjev za izručenje treće države s kojom je prva država članica zaključila sporazum o izručenju, ona je dužna izvijestiti državu članicu čiji je navedeni građanin državljanin te, ovisno o okolnostima, na zahtjev te države članice predati toga građanina u skladu s Okvirnom odlukom o EUN-u, pod uvjetom da je ta država u skladu sa svojim nacionalnim pravom nadležna za kazneni progon te osobe za djelo počinjeno izvan njezina državnog područja. ${ }^{53}$

Pokušamo li ilustrativno prikazati navedenu situaciju na primjeru Hrvatske i $\mathrm{BiH}$, može se dogoditi da BiH kao treća država zatraži izručenje osobe koja se nalazi u Hrvatskoj, a koja je državljanin neke druge države članice EU-a (primjerice Slovenije) radi kaznenog progona za kazneno djelo počinjeno u BiH. U tom slučaju Hrvatska bi bila dužna izvijestiti Sloveniju o zahtjevu za izručenje od BiH te ga predati Sloveniji na njezin zahtjev ako je Slovenija po svome nacionalnom pravu nadležna za kazneni progon za djelo počinjeno izvan svoga teritorija. Tu se postavlja pitanje primarne primjene Ugovora o izručenju između Hrvatske i BiH ili Okvirne odluke o EUN-u. Taj

${ }^{51}$ Kazneni zakon, NN, br. 125/11, 144/12, 56/15, 61/15, 101/17, 118/18.

52 Izvadak iz Odluke Ustavnog suda Hrvatske br. U-III-4161/2017 od 15. studenoga 2017.

53 Točka 50. presude Suda EU-a u predmetu Aleksei Petruhhin br. C-182/15 od 6. rujna 2016. godine. 
je primjer prakse Suda EU-a poslije korišten u sličnim predmetima poput predmeta Romano Pisciotti, Denis Raugevicius i sl.

Drugi primjer koji se tiče izručenja stranca pojavljuje se u zahtjevu Hrvatske gdje se od Suda EU-a traži objašnjenje treba li članak 18. UFEU-a tumačiti na način da je država članica EU-a koja odlučuje o izručenju trećoj državi (Ruskoj Federaciji) državljanina države koja nije članica EU-a, ali je članica šengenskog područja, obvezna o zahtjevu za izručenje izvijestiti državu članicu šengenskog područja čija je ta osoba državljanin? ${ }^{54}$ lako nije predmet ovog rada, takva situacija može se dogoditi i u odnosu na Hrvatsku i BiH. Primjerice, da BiH kao treća država traži od Hrvatske izručenje državljanina Islanda kao države koja nije država članica EU-a, ali je država članica šengenskog prostora. Pitanje je za neke druge rasprave treba li Hrvatska o zahtjevu za izručenje izvijestiti Island u skladu sa Sporazumom između EU-a i Republike Islanda i Kraljevine Norveške o postupku predaje između država članica EU-a i Islanda i Norveške ili odlučivati o zahtjevu u skladu s Ugovorom. S obzirom na to da je navedeni primjer novijega datuma te da Sud EU-a još nije o tome odlučio, ostaje pričekati njegovo tumačenje u vezi s tim pitanjem.

Analizom navedene prakse uočavamo kako države članice široko tumače načelo neizručenja vlastitih državljana pozivajući se na jednako postupanje prema građanima EU-a u odnosu na njihovo izručenje trećim državama, ali i upozoravaju na problem koji zahtijeva konsenzus na međunarodnoj razini. Prihvaćanje prakse Suda EU-a kojom bi se utvrdilo da je izručenje drugih građana EU-a državama nečlanicama EU-a diskriminacija na temelju državljanstva relativiziralo bi institut izručenja uopće i smanjilo učinkovitost sustava represije međunarodnoga kaznenog prava. Da bi se taj problem mogao učinkovito riješiti i omogućiti ostvarenje pravosudne suradnje država članica i nečlanica EU-a, odnosno općenito država kao subjekata međunarodnog prava, potrebno je najprije poći od cilja izručenja. Izručenje je najstariji institut međunarodnopravne pomoći čiji je cilj borba protiv kriminaliteta i borba protiv nekažnjavanja.

Cilj je ekstradicije onemogućiti okrivljeniku da izbjegne kaznenopravni progon, a postizanje tog cilja moguće je i bez inzistiranja na uniformnosti kaznenopravnih sustava upravo na temelju činjenice da različiti sustavi dijele iste temeljne vrijednosti $i$ da suradnja može biti utemeljena upravo na tim zajedničkim vrijednostima. ${ }^{55}$ Široko oslanjanje na načelo neizručenja vlastitih državljana onemogućava ostvarenje toga cilja, osobito što države ne poštuju potpuno uspostavljene međunarodne standarde

\footnotetext{
${ }_{54}$ Zahtjev za donošenje prethodne odluke sa zahtjevom za odlučivanje u hitnom prethodnom postupku, Vrhovni sud Republike Hrvatske od 28. studenog 2019. godine, dostupan na http://www.vsrh. hr/CustomPages/Static/HRV/Files/2019dok/Priopcenja/002-C-897-19_PPU-1-1136296-HR-C204770.pdf (pristupljeno 5. 1. 2020.).

55 Derby 1991, 61.
} 
koji se tiču obveze preuzimanja kaznenog progona u slučaju neizručenja vlastitoga državljanina. Također, potrebno je jačati načelo uzajamnog povjerenja, što bi dovelo do relativiziranja načela neizručenja vlastitih državljana.

Da je pitanje izručenja vlastitih državljana aktualno u suvremenome kaznenom pravu, potvrđuje i nedavni pokušaj donošenja zakona o izručenju kojim bi se građane Hong Konga za kaznena djela izručivalo Kini. Inače, Hong Kong bivša je britanska koIonija koja je 1997. godine vraćena Kini u okviru dogovora „jedna država, dva sustava“ koji jamči određenu razinu autonomije. Hong Kong danas djeluje kao samostalna država i njezino sudstvo djeluje pod sustavom običajnog prava koji se razlikuje od kontinentalne Kine. Međutim, kritičari tvrde da upravo takav sustav pogoduje počinjenju kaznenih djela te je taj zakon o izručenju imao cilj suzbiti kriminalitet izručivanjem hongkonških stanovnika Kini.

\section{PRAVOSUDNA SURADNJA HRVATSKE I BIH U POSTUPCIMA IZRUČENJA VLASTITIH DRŽAVLJANA U PRAKTIČNIM PRIMJERIMA}

Pravosudnu suradnju Hrvatske i BiH u postupcima izručenja vlastitih državljana možemo podijeliti na razdoblje prije potpisivanja Ugovora i nakon njegova potpisivanja. Prije potpisivanja Ugovora te dvije države nisu imale praksu izručivati vlastite državljane, nego su se ekstenzivno pozivale na svoje ustavne (Hrvatska) i zakonske $(\mathrm{BiH})$ ovlasti. lako neki praktični primjeri pokazuju da i u vrijeme neprimjene Ugovora nije bilo sasvim opravdano načelo neizručenja vlastitoga državljanina, ono se ipak koristilo kao razlog odbijanja izručenja. Takav primjer sudske praske uočavamo u predmetu gdje državljanin obiju država (i Hrvatske i BiH) kojega traži Hrvatska nije izručen zbog činjenice da ima državljanstvo. U tom je predmetu Izvanraspravno vijeće Suda BiH u svojoj odluci zaključilo da ZKP BiH isključuje mogućnost izručenja bosanskohercegovačkih državljana te da takva obveza nije predviđena bilo kojim međunarodnim pravnim aktima. ${ }^{56} \mathrm{Sud} \mathrm{BiH}$ takvu je odluku donio bez obzira na tumačenje da je upis $u$ državljanstvo zatražen s očiglednom namjerom izbjegavanja procesuiranja i eventualnih posljedica osude za kazneno djelo ratnoga zločina. Međutim, Sud BiH u tom je predmetu iznio stajalište da se „ekstradicijski pojam državljanstva mora tumačiti tako da se pravo na državljanstvo ne smije svjesno i namjerno koristiti u cilju stjecanja ili zaštite neprava" te se ekstradicijski pojam državljanstva treba uzimati s velikim oprezom i na sudovima dokazati da razlozi stjecanja državljanstva nisu usmjereni zaštiti pojedinaca od izbjegavanja procesuiranja u drugim državama. Uz ostalo, u svojoj odluci Sud BiH navodi i da „između ustavnog cilja i svrhe državljanstva i vršenja pravde kao temeljnog principa moderne države mora

56 Sud BiH, Odluka Izvanraspravnog vijeća br. KV-70/09 od 23. lipnja 2009. godine. 
biti uspostavljena ravnoteža da bi se osigurao pravni poredak na najboljim pravnim standardima" te da u specifičnom kontekstu država u okruženju „kruto tumačenje pojma državljanstva očigledno potkopava pravni poredak i ugrožava pravdu“. ${ }^{57} \mathrm{Na-}$ vedeni predmet okončan je preuzimanjem i izvršenjem kaznenopravne sankcije izrečene pred pravosudnim tijelima Hrvatske. Također, poznat je predmet u kojem su osobu osudila pravosudna tijela $\mathrm{BiH}$ te je prije izricanja presude u obnovljenome postupku prebjegla u Hrvatsku čiji je također državljanin. Taj predmet do danas nije okončan zbog odsutnosti osobe koju traži bosanskohercegovačko pravosuđe, a koja se nalazi u Hrvatskoj te zbog hrvatskoga državljanstva nije izručena $\mathrm{BiH} \cdot{ }^{58} \mathrm{Do}$ datan je problem kod tog predmeta nemogućnost vođenja kaznenog postupka u odsutnosti osumnjičenog, što upozorava na nužnu izmjenu kaznenoprocesnog zakonodavstva u BiH po uzoru na sustav kakav postoji u Hrvatskoj. ${ }^{59} \mathrm{~S}$ druge strane, nedavno okončan ekstradicijski predmet, premda okončan neizručenjem vlastitoga državljanina (državljanina koji ima dvojno državljanstvo Hrvatske i BiH), nije imao uporište u načelu neizručenja vlastitoga državljanina zbog državljanstva. ${ }^{60}$ Posljedica je takva postupanja Suda BiH primjena čl. 7. i 8 . Ugovora. Osim navedenog, u praksi se događalo da je osoba čije se izručenje traži počinila kaznena djela prije potpisivanja Ugovora, ali je radnja tih djela činjena i nakon njegova potpisivanja. Stoga se postavlja pitanje tumačenja u vezi s izručenjem vlastitih državljana s obzirom na djela koja čine sadržaj optužnice jer, kako smo naveli, prije potpisivanja Ugovora nije postojala obveza izručenja vlastitih državljana. U jednome novijem predmetu Sud $\mathrm{BiH}$ zauzeo je stajalište da nema zakonskih osnova za izručenje jer sadržaj optužnice čine kaznena djela počinjena prije i samo dio kaznenih djela počinjenih nakon potpisivanja Ugovora. U tom slučaju Sud BiH pozvao se na čl. 40. ZMPPKS-a BiH prema kojem BiH ne izručuje vlastite državljane te se Ugovor ne može retroaktivno primjenjivati. Dakle, za djela počinjena prije potpisivanja Ugovora mora postojati jasna politička volja tih dviju država za izručivanje vlastitih državljana te povjerenje u pravosudne sustave obiju država, osobito imajući u vidu dugogodišnju pravosudnu suradnju u kaznenim stvarima. Također, valja istaknuti da se odredbe Ugovora o izručenju vlastitih državljana tiču samo određenih kaznenih djela zbog čega govorimo o njegovoj ograničenoj primjeni. Dakle, vlastiti se državljani i prema Ugovoru mogu izručiti samo za određena kaznena djela. ${ }^{61} \mathrm{~S}$ obzirom na to da je priroda navedenih djela takva da su ona većinom sastavljena od niza protupravnih radnja u duljem razdoblju, sadašnjom regulativom može se dogoditi da vlastiti državljani

\footnotetext{
57 Sud BiH, Rješenje br. Ex-21/09 od 14. svibnja 2009. godine.

58 Sud BiH, br. S1 2 K 01317706 Kžk (KPŽ-47/05) od 17. srpnja 2006. godine.

59 Čl. 402., st. 3. Zakona o kaznenom postupku, NN, br. 152/08, 76/09, 80/11, 121/11, 91/12, 143/12, 56/13, $145 / 13,152 / 14,70 / 17$

60 Sud BiH, br. S1 3 K 02882719 Kž 2 od 23. rujna 2019. godine.

${ }^{61}$ Vidjeti supra, 11.
} 
ne budu izručeni ne zbog državljanstva, nego zbog činjenice da ta djela čine sadržaj optužnice koja je podignuta nakon potpisivanja Ugovora, ali je djelo činjeno i prije i nakon potpisivanja Ugovora.

Poredbenim rješenjima ${ }^{62}$ uočavamo da primjerice Ugovor o izručenju između EU-a i SAD-a u čl. 16. propisuje njegovu primjenu na kaznena djela počinjena prije i poslije njegova stupanja na snagu. ${ }^{63}$ Po uzoru na taj ugovor potpisan je Ugovor između SAD-a i Srbije koji u čl. 21. također predviđa retroaktivnu primjenu Ugovora na kaznena djela počinjena prije i poslije njegova stupanja na snagu pod uvjetom da izvršno tijelo zamoljene države ima diskrecijsko pravo ne izručiti vlastitoga državljanina za kaznena djela počinjena prije 1. siječnja 2005. godine. ${ }^{64}$ Bi li retroaktivna primjena Ugovora na djela s popisa u slučaju izručenja vlastitih državljana uz diskrecijsko pravo zamoljene države da odbije izručiti vlastitoga državljanina iz opravdanih razloga (npr. neistovjetnosti norme) doprinijela učinkovitijoj borbi protiv teških oblika kriminaliteta i pravosudnoj suradnji Hrvatske i $\mathrm{BiH}$, ostaje pitanje za neke daljnje rasprave. U svakom slučaju treba imati na umu aktualne odredbe Ugovora koje eksplicitno navode da se vlastiti državljani mogu izručiti za kaznena djela počinjena samo nakon potpisivanja Ugovora, dakle od 28. studenog 2012. godine. Kad je riječ o statističkim podatcima u vezi s izručenjem između Hrvatske i BiH, od 2015. do 2018. godine bila su ukupno 64 ekstradicijska predmeta kako slijedi u tablici:

\begin{tabular}{|c|c|c|}
\hline Godina & iz BiH & u BiH \\
\hline 2015. & 11 & 16 \\
\hline 2016. & 27 & 8 \\
\hline 2017. & 30 & 6 \\
\hline 2018. & 17 & 13 \\
\hline
\end{tabular}

Osim toga, u navedenom razdoblju bilo je ukupno sedam predmeta izručenja vlastitih državljana, i to po molbi Ministarstva pravosuđa Hrvatske šest i po molbi Ministarstva pravde $\mathrm{BiH}$ jedan. Po molbi BiH iz 2016. godine postupak je u tijeku, dok je po molbi Hrvatske u dvama slučajevima odbijeno izručenje jer nisu bile ispunjene zakonske pretpostavke (predmeti iz 2015. i 2018. godine), u trima je slučajevima

\footnotetext{
62 Takvu odredbu sadržava i Dopunski sporazum između Kanade i Njemačke koji u čl. 16. pod nazivom „Retroaktivnost“ navodi kako se taj sporazum primjenjuje u svim slučajevima kad se zahtjev za izručenje podnosi nakon njegova stupanja na snagu bez obzira na to je li kazneno djelo počinjeno prije ili poslije toga datuma. Supplementary Treaty to the Treaty Between Canada and the Federal Republic of Germany Concerning Extradition, dostupno na https://www.treaty-accord.gc.ca/text-texte. aspx?id=104859 (pristupljeno 1. 10. 2019.).

${ }_{63}$ Sporazum o izručenju između EU-a i SAD-a, dostupno na https://eur-lex.europa.eu/legal-content/ HR/TXT/PDF/?uri=CELEX:22003A0719(01)\&from=EN (pristupljeno 19. 9. 2019.).

${ }^{64}$ Ugovor o izručenju između SAD-a i Srbije, dostupno na https://www.state.gov/wp-content/uploads/2019/06/19-423-Serbia-Extradition.pdf (pristupljeno 20. 9. 2019.).
} 
postupak u tijeku (predmeti iz 2019. godine) i u jednom je slučaju izručen vlastiti državljanin Hrvatskoj (predmet iz 2019. godine). Dakle, od četiriju predmeta iz ove godine jedan je državljanin izručen, kod triju predmeta postupak je u tijeku te je u još dva predmeta iz prethodnih godina odbijeno izručenje vlastitoga državljanina Hrvatskoj. Cledajući ukupan broj izručenja od 2011. do 2013. između Hrvatske i BiH, bila su ukupno 93 ekstradicijska predmeta, dok je prema navedenoj tablici za duži period, dakle od 2015. do 2018. godine, ukupan broj izručenja 64. Osim toga, kako se procjenjuje u Ministarstvu pravde $\mathrm{BiH}$, BiH odbije oko $30 \%$ izručenja zbog državljanstva. Međutim, prema navedenim posljednjim podatcima taj postotak pretendira smanjenju upravo zbog Ugovora kao izvora kojim se dopušta izručenje vlastitih državljana.

Dakle, iz svega navedenog uočavamo da je u navedenom razdoblju evidentiran malen broj postupaka izručenja vlastitih državljana, što možemo pripisati činjenici da se nakon zaključivanja Ugovora države ne mogu ekstenzivno pozivati na činjenicu državljanstva kao razlog odbijanja izručenja. To potvrđuje i pozitivna sudska praksa Hrvatske u predmetu u kojem se pozivalo na državljanstvo kao razlog neizručenja, a koje je relativizirano upravo odredbama čl. 7. i 8. Ugovora. ${ }^{65}$ Treba na kraju naglasiti da i broj neizručenja vlastitih državljana nakon potpisivanja Ugovora nije zbog činjenice da imaju državljanstvo, nego eventualno zbog identiteta norme kaznenih djela s popisa iz Ugovora.

\section{ZAKLJUČAK}

Države kao subjekti međunarodnog prava nužno surađuju u kaznenim stvarima. Osobito su složne u borbi protiv svih oblika kriminaliteta koji prelaze granice državnog teritorija. Izručenje kao najstariji institut takva oblika suradnje ima cilj sankcionirati počinitelja kaznenih djela koji se nalaze na državnom području druge države te se tim mehanizmom kaznenopravne pomoći omogućava njihovo procesuiranje ili izdržavanje kaznenopravne sankcije pred represivnim tijelima one države gdje je počinjeno kazneno djelo. Ovim radom posebno je problematizirano pitanje (ne)izručenja vlastitih državljana te su detektirani njegovi učinci na kaznenopravne sustave Hrvatske i BiH. Najveći je problem koji prouzročuje načelo neizručenja vlastitih državljana izbjegavanje kaznenog postupka ili izvršenja kaznenopravne sankcije, što je apsolutno suprotno svrsi kažnjavanja i svrsi izricanja kaznenopravnih sankcija kao temelja kaznenog pravosuđa. Analizom temeljnih teorijskih smetnji izručenju vlastitih državljana utvrdili smo da, barem u primjeru Hrvatske i BiH, više ne postoji pravni temelj pozivanja na načelo neizručenja vlastitih državljana. Premda je dvojno

\footnotetext{
${ }^{65}$ Rješenje Vrhovnog suda Republike Hrvatske, br. I Kž 321/2017-4 od 8. lipnja 2017.
} 
državljanstvo pogodnost koju osumnjičenici uvelike koriste kako bi izbjegli kazneni progon ili izvršenje kaznene sankcije, na državljanstvo se državljani Hrvatske i BiH više ne mogu pozivati. Analizirajući odredbe Ugovora o izručenju između Hrvatske i BiH, utvrdili smo da je on na određen način odstupio od tog načela te predviđa izručenje vlastitih državljana, ali uz neka ograničenja. O pozitivnoj praksi izručenja vlastitih državljana govore i statistički pokazatelji kao i sudska praksa nakon potpisivanja Ugovora koji idu u prilog izručenju vlastitih državljana. Eventualne zapreke izručenju vlastitih državljana više nisu uvjetovane državljanstvom, nego nepostojanjem istovjetnosti norme kaznenih djela s popisa iz Ugovora. Međutim, i taj je razlog relativiziran oslanjajući se na tumačenja sudova i poredbena rješenja kao i moderne instrumente pravosudne suradnje. Također, sudska praksa tih dviju država pokazuje da, zbog nemogućnosti retroaktivne primjene Ugovora kakva je utvrđena u poredbenim rješenjima, neki predmeti ostaju neprocesuirani. Da bi se osigurala učinkovita borba protiv nekažnjavanja osumnjičenika ili osuđenika, države moraju razvijati povjerenje u pravosudne sustave drugih država i omogućiti jednako postupanje prema svim počiniteljima kaznenih djela, i prema strancima i prema vlastitim državljanima. Temelji načela neizručenja vlastitih državljana i u suvremenome kaznenom pravu vrlo su krhki. Imajući u vidu cilj što ga institut izručenja ima u međunarodnim odnosima država, države svoje odnose i pravosudnu suradnju trebaju temeljiti na zajedničkim vrijednostima i zajedničkim pravnim tradicijama radi realizacije sukladnih političkih interesa te represije kriminaliteta.

\section{LITERATURA}

1. Cherif Bassiouni, M. (2008). International Criminal Law, Vol. 2, Multilateral and Bilateral Enforcement Mechanisms, 3rd Ed. Martinus Nijhoff Publishers, Leiden; https://doi.org/10.1163/ej.9789004165311.i-602

2. Deen-Racsmány, Z.; Blekxtoon, J. R. (2005). The Decline of the Nationality Exception in European Extradition, European Journal of Crime, Criminal Law and Criminal Justice, 13 (3), str. 317-364. https://doi.org/10.1163/1571817054604092

3. Degan, V. M.; Pavišíć, B. (2005). Međunarodno kazneno parvo. Pravni fakultet Sveučilišta u Rijeci, Rijeka.

4. Derby, D. H. (1991). Comparative extradition systems, International Review of Penal Law, 62 (1/2), str. 53-61.

5. Derenčinović, D. (2014.). Ulazi li zastara u pojam dvostruke kažnjivosti pri primjeni europskog uhidbenog naloga?, Informator, 62 (6256), str. 1-3.

6. Grotius, H. (1625). De jure belli ac pacis, prijevod na francuski, Barbeyrac, ]. (1724). Pierre de Coup, Amsterdam.

7. Horović, S.; Miljko, Z. (2014). Ustavni i kaznenopravni aspekt prava izručenja (ekstradicije), Zbornik radova Pravnog fakulteta Sveučilišta u Mostaru, (XXII-XXIII), str. 26-50. 
8. Horvatić, Ž. (2002). Rječnik kaznenog prava, Masmedia. Zagreb.

9. Hržina, D.; Rošić, M.; Stipišić, Lj. (2012). Postupci izručenja u Republici Hrvatskoj - praktični aspekti. Hrvatski ljetopis za kazneno pravo i praksu, 19 (2), str. 843-868.

10. Hržina, D. (2016). Međunarodna pravna pomoć i pravosudna suradnja u kaznenim stvarima teorijski i praktični aspekti. Pravosudna akademija, Zagreb.

11. Krapac, D. (2005). Novi Zakon o međunarodnoj pravnoj pomoći u kaznenim stvarima: načela i postupci. Hrvatski ljetopis za kazneno pravo i praksu, 12 (2), str. 625-680.

12. Krapac, D. (2006). Međunarodna kaznenopravna pomoć. Narodne novine, Zagreb.

13. Primorac, D. (2018). Europski uhidbeni nalog - teorija i praksa. Alfa d. d., Zagreb.

14. Primorac, D.; Krmek, M.; Pilić, M. (2015). Teorijska i praktična problematika europskog uhidbenog naloga bez provjere dvostruke kažnjivosti, u: Zbornik radova međunarodne naučno-stručne konferencije "Usklađivanje zakonodavstva s AQUIS-em", MasterVision d.o.o., Sarajevo.

15. Shearer, I. A. (1966). Non-extradition of nationals - A Review and Proposal. Adelaide Law Review, 2 (3), str. 273-309.

16. Sladoje, N.; Bučar, A.; Pilav, A.; Šarac, J. (2006). Međunarodna pravna pomoć. Ministarstvo pravde $\mathrm{BiH}$, Sarajevo.

17. Thouvenin, J-M. (2012). Le principe de non extradition des nationaux, u: Droit international et nationalité, Colloque de Poitiers de la Société française pour le droit international. Pedone, Paris, str. 127-144.

Pravni izvori:

1. Constitution fédérale de la Confédération suisse du 18 avril 1999 (Etat le 23 septembre 2018), https://www.admin.ch/opc/fr/classified-compilation/19995395/index.html.

2. Décret $n^{\circ}$ 2002-117 du 29 janvier 2002 portant publication du traité d'extradition entre la France et les Etats-Unis d'Amérique (ensemble un procès-verbal d'accord sur la représentation), signé à Paris le 23 avril 1996 (1), https://www.legifrance.gouv.fr/affichTexte. do?cidTexte=JORFTEXTo00000218360\&categorieLien=id.

3. Document A/CN.4/579 and Add.1-4, (2007.). The obligation to extradite or prosecute (aut dedere aut judicare), Comments and observations received from Covernments, http://legal.un.org/docs/?path=../ilc/documentation/english/a_cn4_579.pdf\&lang=ESX.

4. Europska konvencija o izručenju 13. prosinca 1957. godine, https://narodne-novine.nn.hr/ clanci/medunarodni/1994_12_14_57.html.

5. Germany International Extradition Treaty with the United States from June 20, 1978, http://www.mcnabbassociates.com/Cermany\%2olnternational\%20Extradition\%20 Treaty\%20with\%20the\%2oUnited\%20States.pdf.

6. Crundgesetz für die Bundesrepublik Deutschland, https://www.gesetze-im-internet.de/ gg/B]NRoooo10949.html.

7. Inter American Convention of Extradition from December 26, 1933, https://www.oas.org/ juridico/english/treaties/b-47.html. 
8. Kazneni zakon FBiH, Službene novine Federacije BiH, br. 36/03, 21/04 - ispr., 69/04, 18/05, 42/10, 42/11, 59/14, 76/14, 46/16, 75/17.

9. Kazneni zakon, NN, br. 125/11, 144/12, 56/15, 61/15, 101/17, 118/18.

10. Konvencija sastavljena na temelju članka K.3 Ugovora o Europskoj uniji o izručenju između država članica Europske unije, dostupno na https://eur-lex.europa.eu/legal-content/HR/TXT/?uri=CELEX\%3A41996A1023\%2802\%29.

11. Latvijas Republikas Satverse, https://likumi.Iv/doc.php?id=57980.

12. Sporazum između Vlade BiH, Vlade FBiH i Vlade Hrvatske o pravnoj pomoći u građanskim i kaznenim stvarima s posebnim dodatkom, NN-Međunarodni ugovori, br. $12 / 96$.

13. Sporazum između Vlade BiH, Vlade FBiH i Vlade RH o međusobnom izvršavanju sudskih odluka u kaznenim stvarima, Službeni list RBiH, Međunarodni ugovori, br. 1/96.

14. Suomen perustuslaki, https://www.finlex.fi/fi/laki/ajantasa/1999/19990731.

15. Supplementary Treaty to the Treaty Between Canada and the Federal Republic of Cermany Concerning Extradition, https://www.treaty-accord.gc.ca/text-texte.aspx?id=104859.

16. Treaty Between the Government of Canada and the Government of the Italian Republic Concerning Extradition, dostupno na https://www.treaty-accord.gc.ca/text-texte.aspx?id=105016.

17. Ugovor između Bosne i Hercegovine i Republike Hrvatske o dvojnom državljanstvu, NN, br. 9/07, Službeni glasnik BiH, Međunarodni ugovori, br. 10/11.

18. Ugovor između Republike Hrvatske i Bosne i Hercegovine o izručenju, NN-Međunarodni ugovori br. 1/14, Službeni glasnik BiH, Međunarodni ugovori, br. 22/12

19. Ugovor o izručenju između EU-a i SAD-a, https://eurlex.europa.eu/legalcontent/HR/ TXT/PDF/?uri=CELEX:22003A0719(01)\&from=EN.

20. Ugovor o izručenju između SAD-a i Srbije, https://www.state.gov/wp-content/uploads/2019/06/19-423-Serbia-Extradition.pdf.

21. Ustav Bosne i Hercegovine, http://www.ccbh.ba/public/down/USTAV_BOSNE_I_HERCEGOVINE_bos.pdf.

22. Zahtjev za donošenje prethodne odluke sa zahtjevom za odlučivanje u hitnom prethodnom postupku, Vrhovni sud Republike Hrvatske od 28. studenog 2019. godine, http:// www.vsrh.hr/CustomPages/Static/HRV/Files/2019dok/Priopcenja/o02-C-897-19_PPU-11136296-HR-G204770.pdf.

23. Zakon o državljanstvu Bosne i Hercegovine, Službeni glasnik BiH, br. 4/97, 13/97, 41/02, 6/03, 14/03.

24. Zakon o hrvatskom državljanstvu, NN, br. 53/91, 28/92, 113/93, 4/94, 130/11, 110/15.

25. Zakon o kaznenom postupku, NN, br. 152/08, 76/09, 80/11, 121/11, 91/12, 143/12, 56/13, 145/13, 152/14, 70/17.

26. Zakon o kaznenom postupku BiH, Službeni glasnik Bosne i Hercegovine, br. 3/03, 32/03, 36/03, 26/04, 63/04, 13/05, 48/05, 46/06, 29/07, 53/07, 58/08, 12/09, 16/09, 53/09, 93/09, 72/13, $65 / 18$ 
27. Zakon o krivičnom postupku SFR], Službeni list SFR], br. 4/77, 36/77, 60/77, 14/85, 26/86, 74/87, 57/89, 3/90 i Službeni list SR], br. 27/92, 24/94, 13/01.

28. Zakon o međunarodnoj pravnoj pomoći u kaznenim stvarima, NN, br. 178/04.

29. Zakon o međunarodnoj pravnoj pomoći u kaznenim stvarima, Službeni glasnik BiH, br. $53 / 09,58 / 13$.

Sudska praksa:

1. Odluka Ustavnog suda Hrvatske br. U-III-4161/2017 od 15. studenoga 2017.

2. Presuda Europskog suda za ljudska prava od 4. rujna 2014., Trabelsi protiv Belgije, dostupno na https://hudoc.echr.coe.int/eng\#\{\%22itemid\%22:[\%22001-146372\%22]\}.

3. Presuda Suda EU-a u predmetu Aleksei Petruhhin br. C-182/15 od 6. rujna 2016. godine 4. Rješenje Vrhovnog suda Republike Hrvatske, br. I Kž 321/2017-4 od 8. lipnja 2017.

5. Sud BiH, Odluka Izvannraspravnog vijeća br. KV-70/09 od 23. lipnja 2009. godine.

6. Sud BiH, Rješenje br. Ex-21/09 od 14. svibnja 2009. godine.

7. Sud BiH, br. S1 2 K 01317706 Kžk (KPŽ-47/05) od 17. srpnja 2006. godine.

8. Sud BiH, br. S1 3 K 02882719 Kž 2 od 23. rujna 2019. godine.

\section{Summary}

\section{THEORETICAL AND PRACTICAL ASPECTS OF JUDICIAL COOPERATION BETWEEN CROATIA AND BOSNIA AND HERZEGOVINA IN EXTRADITING THEIR CITIZENS}

The institute of extradition is the oldest form of international legal assistance which has been replaced by the European arrest warrant in Member States of the European Union. Regarding the third countries, such as Bosnia and Herzegovina, extradition is the only instrument enabling the transfer of persons that have to be extradited for criminal trial, imprisonment, or any other measure of deprivation offreedom in the applicant state. In an effort to ensure legal certainty, the principle of legality and the rule of law, states as subjects of international law increasingly regulate their relations in the field of extradition law by signing bilateral agreements in order to achieve that aim. Within this framework, Croatia and Bosnia and Herzegovina concluded the Treaty on Extradition on 28 November 2012. The Treaty was applied temporarily starting from the above date, and it came into force on 6 March 2014. The Treaty regulates the extradition of citizens, departing from the traditional principle of non-extradition of a state's own citizens. The authors analyse the Treaty on Extradition with a special focus on extradition of a country's own citizens, especially those with dual citizenship, which is often the case with citizens of Croatia and Bosnia and Herzegovina. Many European and world countries strongly oppose the extradition of their own citizens. The principle of non-extradition of a country's own citizens is based on the concept of the sovereignty of states and their citizens and their mutual obligations, and it is often a consequence of distrust of judicial 
systems of other states. However, bearing in mind that the fundamental aim of extradition is the struggle against the absence of punishment for persons suspected or convicted of criminal offences, distrust as a reason for non-extradition should be taken with the greatest caution. The fact that the principle of non-extradition of a state's own citizens is outdated in modern criminal law is confirmed by the Convention on Extradition between EU Member States according to which extradition cannot be rejected because a person is a citizen of applicantstate. The aim of the paper is to draw attention to problems that have an impact on judicial cooperation between Croatia and Bosnia and Herzegovina by analysing the existing normative framework and practical examples of (non)extradition of citizens of one's own state and offer a contribution to solve these important issues.

Key words: judicial cooperation, extradition, extradition agreement, (non)extradition of one's own citizens, case law 